Article

\title{
Determinants of Voluntary Greenhouse Gas Emission Disclosure: An Empirical Investigation on Turkish Firms
}

\author{
Halil Emre Akbaş * and Seda Canikli@ \\ Department of Business Administration, Faculty of Economics and Administrative Sciences, Yildiz Technical \\ University, Istanbul 34210, Turkey; scanikli@yildiz.edu.tr \\ * Correspondence: eakbas@yildiz.edu.tr
}

Received: 27 November 2018; Accepted: 19 December 2018; Published: 25 December 2018

\begin{abstract}
Firms worldwide have been facing an increasing pressure to disclose their Greenhouse Gas (GHG) emissions since GHG emissions are seen as the main source of global warming which is one of the most challenging problems that the world is faced with. For this reason, voluntary GHG disclosure represents a growing area of research interest. However, the existing research generally focuses on developed countries. In this sense, the present paper aims to contribute to the existing GHG disclosure literature by analyzing the determinants of voluntary disclosure of firms operating in a developing country, Turkey. The effects of both financial characteristics and board structures of firms on voluntary disclosure decisions are analyzed as the possible determinants of GHG disclosures of Turkish firms. We use two proxies for assessing the firms' GHG disclosures. The first proxy, "sensitiveness tendency", indicates the response behavior of firms to the Carbon Disclosure Project (CDP) survey. The second proxy, namely, "transparence tendency", represents the disclosure behavior of firms. Using logistic regression models with a sample of 84 listed Turkish companies which were included in the Carbon Disclosure Project survey in 2014, 2015 and 2016, we find that firm size, institutional ownership and market value are positively related to the sensitivity of sampled firms, while board size is negatively related. On the other hand, our results indicate that firm size, profitability and institutional ownership have positive impacts on the transparency of Turkish listed firms.
\end{abstract}

Keywords: greenhouse gas disclosure; global warming; Turkish firms; firm characteristics; corporate governance; Carbon Disclosure Project

\section{Introduction}

Climate change, in other words, global warming has been regarded as one of the major environmental issues that the world is faced with in the 21st century [1-6]. In simple terms, global warming represents a rise in the average temperature of the earth's near-surface air and oceans [7]. According to the Fifth Assessment Report of The Intergovernmental Panel on Climate Change (IPCC) which was founded by the United Nations Environment Programme and the World Meteorological Organization for the purpose of providing the most updated and comprehensive scientific, technical and socio-economic information about climate change, the globally averaged combined land and ocean surface temperature rose approximately $0.85^{\circ} \mathrm{C}$ over the period of 1880 to 2012. Furthermore, it is also stated that each of the last three decades has been warmer than any preceding decade since 1850 and it was very likely that the period from 1983 to 2012 was the warmest 30-year period of the last 800 years in the Northern Hemisphere [8,9]. There are obvious impacts of climate change on natural and human systems all over the world such as changes in the distribution of precipitation, the 
intensity and frequency of floods and droughts, the water resources in terms of quantity and quality, food security and the rise in sea level, and these impacts are expected to continue and dramatically affect the well-being of billions of people throughout the world [7,9-11].

There is a growing scientific evidence that indicates that greenhouse gas (GHG) emissions from human-related activities are the main causes of global warming [6,12-15]. Furthermore, in recent studies, there is evidence that a positive relationship exists between carbon emissions, energy consumption and economic development [16-18]. GHGs which help to absorb and emit radiation within the thermal infrared range mainly consist of carbon dioxide, methane and nitrous oxide [8,19-21]. The report of IPCC demonstrates that concentrations of carbon dioxide, methane and nitrous oxide in the atmosphere have increased substantially since 1750 (40\%, 150\% and 20\% respectively). Especially, emissions reached the highest levels over the period of 2000 to 2010. Carbon dioxide which can be seen as the most important greenhouse gas increased from $278 \mathrm{ppm}$ in around 1750 to $390.5 \mathrm{ppm}$ in 2011. During the same period, methane increased from $722 \mathrm{ppb}$ to $1803 \mathrm{ppb}$ and nitrous oxide $271 \mathrm{ppb}$ to $324.2 \mathrm{ppb}$. It is obvious that the concentrations of these three gases reached the levels that are the highest in at least the last 800,000 years. Furthermore, the average rate of increase of these GHGs observed over the past century is higher than any observed rate of change over the previous 20,000 years [21].

Companies have been facing an increasing pressure to asses, reduce and report their GHG emissions from different types of stakeholders, such as consumers, governments, suppliers, investors, financial institutions, media, non-governmental organizations and the general public as corporate activities have a significant effect on the global GHG emissions, directly or indirectly [7,11,22-25]. In order to respond to these pressures, a growing number of companies around the world have started to establish strategies and take actions to mitigate their carbon footprint and disclose information about GHG emissions by using various channels of communication $[11,26,27]$.

In line with these developments, a growing number of voluntary or mandatory reporting schemes under which companies report GHG emissions have been introduced by a number of governments such as United States of America, Australia, Canada, France, Japan, Israel, Korea, New Zealand and United Kingdom [28]. In addition to government reporting schemes, a variety of non-governmental initiatives have emerged for the purpose of encouraging or pressurizing companies to disclose information about their effects on the ecological environment and environmental performance, including GHG emissions. Examples of these initiatives include the Carbon Disclosure Project (CDP), the Institutional Investor Group on Climate Change (IIGCC), the Investor Network on Climate Risk (INCR), the Global Reporting Initiative (GRI), the International Integrated Reporting Committee (IIRC) and initiatives of the World Economic Forum (WEF) [23,28-33]. It would not be wrong to say that the CDP, which is a not-for-profit and investor-backed organization, represents the most established and prominent institution with regard to GHG emission disclosure. CDP annually collects information related to GHG emissions, climate change risks and opportunities and management strategies of the largest companies across the world by sending a standard and well-designed questionnaire. The first questionnaire was sent by CDP in 2003 to FT Global 500 firms and 220 of them responded. Since then, the number of companies disclosing GHG emissions through CDP has grown rapidly and by 2017 that number reached 2418 companies all over the world [12,22,25,26,31,34].

Despite these developments, it should be noted that GHG emission disclosure is still not mandatory in most of the countries in the world, including Turkey, and companies have developed different strategic approaches with regard to voluntary disclosure of GHG emissions. Some of the companies have avoided transparency and decided not to disclose their GHG emissions while some of the others have chosen to provide detailed information about their GHG performance and emissions voluntarily $[11,25,35]$. Starting from this fact, we attempt to identify the determinants of GHG voluntary disclosure of Turkish firms in the present study. The Turkish business environment, which is characterized by a dominant state, highly concentrated ownership and family-controlled business groups [36,37], has been experiencing intense changes due to the effects of mainly globalization, 
dynamics of international markets and government policies [38]. The examples of these changes include the regulations of Capital Markets Board with regard to corporate governance, enforcement of a new Turkish Commercial Code and adopting International Financial Reporting Standards which are beneficial for the national and international entities, for investors, for auditors and for other stakeholders [39-41]. In addition to these developments, Turkey has demonstrated high economic growth rates, a rapid increase in population and urbanization [42]. Given the effects of these factors on GHG emissions, the GHG disclosure of Turkish firms represents an interesting research area. In this sense, this paper aims to examine which of the key firm characteristics, namely, firm size, profitability, leverage, institutional ownership, industrial membership and market value and corporate governance variables such as board size and independence influence the disclosure of GHG emissions for a sample of 252 firm-year observations listed on the Borsa Istanbul (BIST) over the period 2014-2016. The data related to the GHG disclosures of sampled firms were retrieved from CDP survey reports. We used two proxies for assessing the GHG disclosures of firms. The first proxy, "sensitiveness tendency", indicates the response behavior of firms to the CDP survey. The second proxy, namely, "transparence tendency" represents the disclosure behavior of firms. The results of the study indicate that firm size and institutional ownership significantly and positively influence the likelihood of GHG disclosure (in terms of both sensitiveness tendency and transparence tendency) while the board size has a negative impact on sensitiveness tendency and profitability has a positive impact on transparence tendency. On the other hand, contrary to our predictions, we could not find any statistical proof for the effects of leverage, industry membership and board independence on both the sensitiveness tendency and transparence tendency.

The present study makes several contributions to the extant GHG disclosure literature. First, it extends the existing literature by analyzing the determinants of voluntary GHG disclosure of firms operating in a developing country, Turkey. Previous studies generally focus on developed countries, and there is still little empirical evidence on the GHG disclosures of firms in developing countries. Nevertheless, GHG emissions may cause more serious problems for developing countries as they generally have higher economic growth rates and excessive fossil fuel consumptions. In this respect, investigating the determinants of GHG disclosures for developing countries can be seen as a necessity [1]. Second, this study analyzes both the sensitivity tendency and transparence tendency related to the GHG disclosures of Turkish companies. Third, whilst most of the prior studies investigate the effects of especially financial characteristics of firms on GHG disclosure, the impact of corporate governance variables are mostly neglected. However, corporate governance, particularly the structure of the board of directors, could be an important factor that can affect GHG disclosures, since firms' disclosure policies, especially policies on voluntary disclosure, are formalized by the board of directors [43-50]. In this sense, this study analyzes the effects of both firms' financial characteristics and board structures on GHG disclosure.

The remainder of the study is structured as follows. The next section outlines the theoretical framework, Section 3 demonstrates the prior literature and develops the hypotheses of the study. Section 4 presents the research methodology while Section 5 reports the results of the study. Finally, Section 6 highlights the concluding remarks and provides future research directions.

\section{Theoretical Framework}

Based on an extensive literature review, Hahn et al. [29] identified three main groups of theories which have been used to explain the voluntary GHG disclosure by firms: Sociopolitical theories, economic theories and institutional theory.

Sociopolitical theories of disclosure assert that the purpose of the voluntary disclosure is not only to provide information about firm activities but also to manage impressions and so to help firms to respond to social and political pressures posed by especially non-market stakeholders (such as NGOs, governments or the media) and/or society as a whole. Stakeholder theory and legitimacy theory represent the two main anchors of the group of sociopolitical theories [29]. 
As mentioned earlier, firms have been facing an increasing pressure from various stakeholders, as a result of increased interest and awareness of the adverse impacts of climate change. According to stakeholder theory, firms have to meet the expectations and gain the support of stakeholders in order to ensure their sustainability. From this point of view, firms have started to disclose more information on the environmental impacts of their activities to present that their activities are in accordance with the expectations of stakeholders. In this framework, stakeholder theory suggests that GHG disclosure represents an effective tool in responding to stakeholders' information demands regarding climate change $[29,33,35]$.

Legitimacy theory provides an alternative theoretical perspective for explaining voluntary environmental disclosure, including GHG disclosure. The main difference between stakeholder and legitimacy theories arises from the actors whom they focus on. Stakeholder theory emphasizes the particular stakeholders' pressures and needs, whereas legitimacy theory focuses on society as a whole [29,35]. In the legitimacy theory framework, firms are just part of a broader social system, and they influence and are influenced by this social system in which they operate. In this regard, it can be easily said that legitimacy theory is fundamentally based on the concept of a "social contract" between the firm and society. According to legitimacy theory, if society perceives that this contract has been broken by the firm, its sustainability will be threatened. Whenever the firm's operations are not meeting the values and expectations of the society or, in other words, the firm is not operating in a legitimate manner, then the society will revoke the firm's contract. This scenario is eligible for especially the topic of climate change which is attracting a growing attention from society all over the world. From this perspective, legitimacy theory emphasizes that GHG disclosure is a means by which firms aim to present that they fulfill the expectations of society and thereby legitimize their operations [29,33,51-53].

Under economic-based theories of disclosure framework, the GHG emission of the firm constitutes a potential source of asymmetric information since the outside stakeholders cannot easily reach credible information. In this respect, signaling theory suggests that firms with better GHG performance will make voluntary GHG disclosure in order to reduce information asymmetry and prevent adverse selection by signaling their superior performance, distinguishing themselves from poor performers. It is also argued that signaling on GHG emissions can improve a firm's image and reputation as increased transparency will be valued by the public, customers, investors and other stakeholders $[12,29,34,53]$.

Institutional theory represents another theoretical framework to explain the motivation of firms to voluntarily disclose GHG emissions. Institutional theory suggests that firms do not solely aim to maximize their profits, but also aim to meet the requirements of different institutions of the society in which they operate. Firms carry out structures, mechanisms and policies in order to comfort these requirements. From this perspective, it is argued that firms can gain credibility and social acceptance by making voluntary GHG disclosures $[29,54,55]$.

Each of the theories mentioned above provide partial, slightly different and useful explanations for the determinants of GHG disclosure [51,54]; there are also some overlaps amongst theories. Furthermore, Hahn et al. [29] states that the results of the empirical studies do not indicate a strong support for only one of these theories. For these reasons, it will be more convenient to consider these different theories as complementary rather than competing explanations for GHG disclosure [56]. We therefore utilize a combined framework when selecting the key firm characteristics and corporate governance variables that may affect GHG disclosure and the development of the hypotheses of the study.

\section{Prior Literature and Hypotheses Development}

Based on the theoretical perspectives and related literature, six firm characteristics: firm size, profitability, leverage, institutional ownership, industrial membership and market value, and two corporate governance variables, namely, board size and board independence are identified as the 
possible determinants of GHG disclosure. Each of these factors and the related hypotheses are depicted as follows.

\subsection{Firm Size}

Previous studies related to environmental issues provide valuable insights into the relationship between firm value and environmental disclosure, environmental performance and financial performance or stakeholder effects on environmental disclosure. The results of the studies show that environmental disclosure is related to financial performance and corporate governance practices. A considerable amount of studies have reported findings with regard to voluntary disclosure, corporate governance and firm value in a positive way [32,57-63]. Many studies indicate that the disclosing firms are more likely to have higher international sales, have lower volatility and be larger in size $[64,65]$.

In the extant literature, firm size has been regularly emphasised as a determinant of voluntary disclosure, hence its effects and pressure have to be mentioned [66] based on the assumption of economies of scale regarding information production cost [67]. Beside this scale, both agency theory and legitimacy theory have arguments about size and disclosure relation [68]. Another reason for a possible association between the size of the firm and voluntary disclosure is provided in the King, Pownall, and Waymire's [69] transactions cost hypothesis. This hypothesis emphasises that voluntary disclosure will increase with firm size due to the fact that incentives for private information acquisition are greater for large firms. In line with this hypothesis, the results of the empirical studies usually indicate a positive relationship between firm size and GHG disclosure behavior e.g., References $[1,11,12,32,70,71]$. Starting from this point, the first hypothesis of this study is formulated as follows:

Hypothesis 1a (H1a). Larger firms are more likely to respond to CDP questionnaires.

Hypothesis $\mathbf{1 b} \mathbf{( H 1 b ) . ~ L a r g e r ~ f i r m s ~ a r e ~ m o r e ~ l i k e l y ~ t o ~ d i s c l o s e ~ r e s u l t s ~ t o ~ t h e ~ p u b l i c . ~}$

\subsection{Profitability}

According to the previous studies, profitability represents another voluntary environmental disclosure determinant. There are two groups of findings, where one side supports the idea that high profit firms do not need voluntary disclosure [72], and the other side supports the idea that high profit is positively related to environmental disclosure tendency. Freedman and Jaggi [73] state that studies placed in the first group are limited and the second group is hegemonic; according to the authors, poor performing firms attempt to justify their performance on heavy pollution expenditures. However, stakeholder theory expects a positive relationship between social disclosures and the economic growth of firms [74]. Many studies relate voluntary GHG disclosure to the profitability, as high profit companies need to be seen as environmentally responsible $[12,52,63,66,75]$. Also, there are studies existing that could not find an association between GHG disclosure and profitability $[34,35,52,76]$. In order to determine the association between profitability and GHG disclosures of Turkish listed firms, we proposed our second hypothesis as;

Hypothesis 2a (H2a). More profitable firms are more likely to respond to CDP questionnaires.

Hypothesis $\mathbf{2 b} \mathbf{( H 2 b )}$. More profitable firms are more likely to disclose results to the public.

\subsection{Leverage}

Jensen and Meckling [77] state that highly leveraged firms disclose more information to the public voluntarily in order to reduce their agency costs, and as a result, reduce the cost of capital in the base of agency theory and stakeholder theory. Prior environmental disclosure research also investigates the effect of indebtedness on disclosure practices as a financial indicator and an accounting-based 
measure. Leverage is a proxy for various dimensions of firm risk $[78,79]$. More leveraged firms are under increased monitoring due to their lower financial flexibility [64]. Both positive and negative relationships between financial risk and GHG disclosure were detected in the literature. Li et al. [80] state that highly leveraged firms are more inclined to disclose information on their GHG emissions. In this sense, it is argued that in order to compensate their shaken reputation, highly leveraged firms tend to disclose details of any increase in firm debt caused by the reduction of GHG emissions. On the contrary, it is argued that firms with a lack of financial resources are less likely to voluntarily disclose carbon information $[34,81]$. We expect that leverage and disclosure behavior have a positive association. In order to test financial debt's effect on GHG disclosure, our hypothesis is as follows:

Hypothesis 3a (H3a). Firms with higher financial risk are more likely to respond to CDP questionnaires.

Hypothesis $\mathbf{3 b} \mathbf{( H 3 b )}$. Firms with higher financial risk are more likely to disclose results to the public.

\subsection{Institutional Ownership}

Recent evidence from the most cited studies shows that ownership structure can be included in the determinants of voluntary environmental disclosure. In line with this evidence, the conflict of interest hypothesis and agency theory emphasizes that profitable associations with the company, large stockholders are effectively put pressure into management [82]. Kim and Lyon [83] demonstrate that institutional investors' consciousness towards climate change can increase shareholder value and awareness of management. Also, the power of institutional investors can create market pressure on firms to reduce their GHG emissions. Besides these suggestions, it is argued that institutional investors incorporate climate risks into their decision-making process when GHG disclosure occurs and they switch their investments to good climate performers [23,84]. There are a large number of studies that exist which identify a significant relationship between GHG disclosure and institutional investors in both positive $[34,35,85,86]$ and negative signs [87]. On the contrary, Hermawan et al. [88] could not detect a significant relation between voluntary disclosure and institutional ownership. We formulate our third hypothesis based on ownership structure as follows:

Hypothesis 4a (H4a). Firms with higher institutional shareholdings are more likely to respond to CDP questionnaires.

Hypothesis $\mathbf{4 b} \mathbf{b} \mathbf{H} 4 \mathbf{b})$. Firms with higher institutional shareholdings are more likely to disclose results to the public.

\subsection{Industrial Membership}

According to an earlier study, different sectors will be faced with different levels and intensities of legitimacy-threatening affects. Legitimacy theory conveys that at given points in time, firms within a sector would experience similar types of legitimacy-threatening affects and so firms in same sector will respond together to a major legitimacy threat [89]. Every sector has its own rules, own needs and own outputs. It is a well-known fact that all sectors do not damage the environment in the same way. The environment is more affected by certain sectors like chemistry, manufacturing etc. Companies that operate in the carbon-intensive sectors (here after CISs) have to behave differently from other sector firms in the frame of voluntary emission disclosure [29]. Many studies report different findings regarding the relationship between (CISs) and GHG disclosure. Ben Amar et al. [34] found a significant association like References $[71,85,90,91]$. There are also a few studies that exist which have found a negative and significant relationship [52,92]. The fifth hypothesis of the study is based on the sector that firms operate in and is formulated as follows:

Hypothesis 5a (H5a). Firms that operate in CISs are more likely to respond to CDP questionnaires. 
Hypothesis $\mathbf{5 b}(\mathbf{H} 5 \mathbf{b})$. Firms that operate in CISs are more likely to disclose results to the public.

\subsection{Market Value}

While the stakeholder theory emphasizes maximizing the total market value of a firm and maximizing the long-term owner value, Jensen [93] states that value maximizing says nothing about creating a superior vision or firm strategy. Hence, it can be important to test whether market value affects the information disclosure strategy of the firm or not. According to the efficient markets hypothesis, new information in the market should be understood in the same way by everyone. Voluntary GHG disclosure provides additional information about the environmental performance of firms, and this information can be a tool for the decision-making process for both current and potential investors in capital markets; investors cannot recognize corporate environmental activity in the absence of corporate disclosure. Thus, market value can be affected by this disclosure behavior or vice versa. Therefore, academicians have searched for this association in extant literature. Saka and Oshika [94] report a statistically significant and positive relationship between disclosures and market value in Japan. By constructing a 42-item disclosure index, Liu et al. [95] and Peng et al. [1] indicate that carbon disclosure is significantly and positively related to market performance. Even companies with a low market value tend to use disclosure to manage information asymmetry. On the other hand, Jacobs et al. [96] state that the market does not react to the Corporate Environmental Initiatives (CEIs) and Environmental Awards and Certifications (EACs) announcements. In order to investigate the market value as a voluntary disclosure determinant, we conduct the hypothesis as follows:

Hypothesis 6a (H6a). Firms with high market value and reputation are more likely to respond to CDP questionnaires.

Hypothesis $\mathbf{6 b}(\mathbf{H 6 b})$. Firms with high market value and reputation are more likely to disclose results to the public.

\subsection{Corporate Governance: Board Size and Independence}

The last determinant of GHG disclosure that we expect is the corporate governance concept. According to the Said et al. [97], corporate governance represents an effective tool which can be used for ensuring that the interests of all stakeholders are protected. In this sense, the board of directors has the task of developing and implementing proper mechanisms to manage, control and report the potential risks, including environmental liabilities. In the literature, many studies emphasise that the influence of the board of directors' structure is quite important on firms' disclosure policy as the final decision-makers. Hence, these studies have determined the corporate governance notion with board characteristics, especially board size and independence in the frame of environmental reporting and disclosure $[7,34,62,71,85,86,98-100]$. In this study, corporate governance is represented with two dimensions as board size in contemplation of increased responsibilities and board independence with the expectation of positively influencing organizational outcomes. Hence, we investigate the association between corporate governance and voluntary GHG disclosure with two different hypotheses as:

Hypothesis 7a (H7a). Firms with larger boards are more likely to respond to CDP questionnaires.

Hypothesis $7 \mathbf{b}(\mathbf{H 7 b})$. Firms with larger boards are more likely to disclose results to the public.

In addition,

Hypothesis 8a (H8a). Firms with independent boards are more likely to respond to CDP questionnaires.

Hypothesis $\mathbf{8 b} \mathbf{( H 8 b )}$. Firms with independent boards are more likely to disclose results to the public. 


\section{Research Methodology}

\subsection{Sample}

In order to examine the determinants of GHG disclosure of Turkish firms, we use the data available from the reports of the CDP-Turkey annual survey for the period 2014-2016. As mentioned earlier, although there are some other institutions or initiatives on environmental disclosure such as IIGCC, INCR, GRI and IIRC, it is possible to say that CDP is the leading institution on GHG disclosure all over world. Each year in Turkey, CDP-Turkey sends a questionnaire on climate change to the Turkish listed firms. The questionnaire consists of five main modules which are "Introduction", "Management", "Risks and Opportunities", "GHG Emissions Accounting, Energy and Fuel Use, and Trading" and "Sign Off". CDP-Turkey sends this questionnaire to firms that are listed on the Borsa Istanbul-100 (BIST-100) index and to firms that answered questionnaire in previous years but are not listed on the BIST-100 index in the current year. In this framework, CDP-Turkey targeted 113 firms in 2014, 111 firms in 2015 and 112 firms in 2016. According to the CDP Climate Change Report 2016-Turkey Edition, the aggregated market capitalization of the firms that answered the questionnaire and disclosed their GHG emissions via CDP, represents $50 \%$ of the total market capitalization of BIST-100 companies [101].

Table 1 presents our sample selection procedure. Our initial sample includes all firms that were targeted by CDP-Turkey in the years 2014-2016. We initially identified a sample of 138 firms. Further, we eliminated the firms that were not targeted in all 3 years and that had missing values with regard to the relevant financial or corporate governance data. After these eliminations, we used a balanced dataset of 84 firms from 10 different sectors, resulting in a final sample of 252 firm year observations.

Table 1. Sample Selection Procedure.

\begin{tabular}{cc}
\hline & Number of Firms \\
\hline All firms that were targeted by CDP-Turkey in the years 2014-2016 & 138 \\
Less & 50 \\
Firms that were not targeted by CDP-Turkey in all 3 years & 4 \\
Firms that had missing financial data & 84 \\
Final Sample & \\
\hline
\end{tabular}

Table 2 presents the sector distribution of the sample based on the Global Industry Classification Standard (GICS). With 20 companies, the materials sector has the highest percentage (23.81\%), followed by the industrial and consumer discretionary sectors (20.24\% and $19.05 \%$, respectively); whereas with one firm, the healthcare and information technology sectors make up the lowest proportions of sampled firms.

Table 2. Distribution of Sampled Firms by Sectors.

\begin{tabular}{ccc}
\hline Sector & Number of Firms & Percentage (\%) \\
\hline Consumer Discretionary & 16 & 19.05 \\
Consumer Staples & 10 & 11.90 \\
Energy & 2 & 2.38 \\
Financials & 11 & 13.10 \\
Healthcare & 1 & 1.19 \\
Industrials & 17 & 20.24 \\
Information Technology & 1 & 1.19 \\
Materials & 20 & 23.81 \\
Telecommunication Services & 2 & 2.38 \\
Utilities & 4 & 4.76 \\
Total & 84 & 100 \\
\hline
\end{tabular}




\subsection{Measurement of Dependent and Independent Variables}

\subsubsection{Dependent Variables}

We use two dependent variables, namely, "sensitivity" and "transparency" to assess the GHG disclosure of Turkish listed firms.

Sensitivity is measured by firms' response behavior to the Carbon Disclosure Project (CDP) questionnaire and is denoted as "RESP". This indicator equals 1 if the firm responded to the questionnaire and 0 otherwise.

Transparency is measured by firms' disclose behavior of the results of the questionnaire and is denoted as "DISC". This indicator equals 1 if the firm responded to the questionnaire and allowed the $\mathrm{CDP}$ to disclose the response to the public and 0 otherwise.

\subsubsection{Independent Variables}

As mentioned earlier, six firm characteristics and two corporate governance characteristics are chosen in this study as the possible determinants of GHG disclosure of Turkish firms. The measurement of each determinant is briefly explained as follows:

As mentioned above, firm size is an important determinant of voluntary GHG disclosure. Previous studies have used many items in order to represent firm size. However, among these items, the most commonly used one is total assets [99,102-105]. Consistent with these studies, we use a firm's total assets at the end of the fiscal year as a proxy of firm size.

As a proxy of firm profitability, we use return on assets (ROA) $[35,66,106,107]$ which is calculated as net income divided by total assets at the end of the fiscal year [12].

Indebtedness can be an effective determinant in the decision-making process and can affect firm behavior in different dimensions. In order to evaluate the association between financial risk and GHG disclosure, we added leverage to the analysis as a proxy for various dimensions of firm risk $[34,64,78,79]$. Leverage is measured as total liabilities divided by total assets at the end of the fiscal year.

The ownership structure of firms is deeply related to GHG disclosure behavior according to the pressure power of share owners on management. Due to the awareness of institutional investors on environmental issues, carbon activities of the firm can be affected by this consciousness [23,35,84]. Thus, our study represents institutional ownership as the portion of institutional shareholders on the equity.

As mentioned above, some sectors have more serious and harmful effects on the environment because of their waste, stack effluents or their fuels. In this research, industrial membership is important, and firms that operate in carbon-intensive sectors are depicted as (CISs) and included into the model as an explanatory variable. This indicator is equal to 1 if the firm operates in a carbon-intensive industry (high-carbon consumption) and 0 otherwise. The high-impact sector list is obtained from Global Reporting Initiative and Association of Chartered Certified Accountants common "High-impact Sectors: The Challenge of Reporting on Climate Change" report which is based on the FTSE4Good index classification and use the FTSE4Good index classification to determine the carbon-intensive sectors.

The same as shareholders, also capital markets and potential investors can put pressure on firms to be aware of the environment. Saka and Oshika [94] and Liu et al. [95] emphasise that current investor dynamics can lead firms to disclose carbon emissions in order to provide information to the market. In line with most of the previous studies [108-110], we measure the market value with the Market-to-Book ratio.

The corporate governance notion is a widely-discussed phenomenon in finance literature that includes both board characteristics and ownership structure. However, in most studies, it is mentioned that board characteristics represents this concept better. Based on extant literature, we construct our model with Board Size and Board Independence which are the measured number of directors on board and the ratio of independent directors on the board, respectively, as the indicators of corporate governance [22,85,86,90,111]. 


\subsection{Empirical Models}

In order to investigate the determinants of voluntary GHG disclosure of Turkish listed firms and to test the hypotheses above, two different binary logistic regression models are conducted. The first model determines the "sensitiveness tendency" of firms which refers to the response behavior to the questionnaire while the second model is conducted to examine the determinants of "transparence tendency" which refers to disclosure behavior. The dependent variable of the first model (RESP) is coded as 1 if the firm responded to the questionnaire and 0 otherwise. DISC which represents the dependent variable of the second model is coded as 1 if the firm responded to the questionnaire and allowed the CDP to disclose the response to the public and 0 otherwise. As the dependent variables of the models are both binary, binary logistic regression models are used in this study. Binary Logistic Regression model represents a proper regression method where the dependent variable is a dummy variable. This model does not assume that there is a linear relationship between the dependent and independent variables [112,113]. In this framework, we adopt the following two binary logistic regression models to test the determinants of GHG disclosure of Turkish listed firms:

Model 1; for sensitivity:

$\operatorname{Ln}\left(\frac{R E S P}{1-R E S P}\right)=\beta 0+\beta 1 T A+\beta 2 R O A+\beta 3 L E V+\beta 4 I N S T S+\beta 5 C I S+\beta 6 M t B+\beta 7 B S I Z E+\beta 8 I N D P+\varepsilon$

Model 2; for transparency:

$L n\left(\frac{D I S C}{1-D I S C}\right)=\beta 0+\beta 1 T A+\beta 2 R O A+\beta 3 L E V+\beta 4 I N S T S+\beta 5 C I S+\beta 6 M t B+\beta 7 B S I Z E+\beta 8 I N D P+\varepsilon$

A summary of the measurement of variables included in the models is presented in Table 3.

Table 3. Variables Used in Logistic Regression Models.

\begin{tabular}{|c|c|c|}
\hline Variables & Abbreviations & Definition \\
\hline \multicolumn{3}{|l|}{ Dependent Variables } \\
\hline Sensitivity & RESP & 1 if the firm responded to the CDP questionnaire and 0 otherwise. \\
\hline Transparency & DISC & $\begin{array}{l}1 \text { if the firm responded to the questionnaire and allowed the CDP to } \\
\text { disclose the response to the public and } 0 \text { otherwise. }\end{array}$ \\
\hline \multicolumn{3}{|l|}{ Independent Variables } \\
\hline Firm Size & TA & Firm's total assets at the end of the fiscal year. \\
\hline Profitability & ROA & Net Income divided by total assets at the end of the fiscal year \\
\hline Leverage & LEV & Total liabilities divided by total assets at the end of the fiscal year \\
\hline Institutional Ownership & INSTS & The proportion of institutional shareholders in equity \\
\hline Industrial Membership & CISs & 1 if the firm operates in a carbon-intensive industry and 0 otherwise \\
\hline Market Value & MtB & Market capitalization divided by stockholders' equity \\
\hline Corporate Governance & BSIZE & Number of directors on the board \\
\hline Corporate Governance & INDP & Percentage of independent directors on the board \\
\hline
\end{tabular}

\section{Results and Discussion}

\subsection{Descriptive Statistics}

Table 4 presents the response rates to the CDP questionnaire of the sampled Turkish listed firms by years. According to Table 4, the average response rate for the sample period is approximately $42 \%$. In contrast, $58 \%$ of the sampled Turkish listed firms did not respond to the CDP questionnaire. The highest response rate was in 2016 , with $45 \%$ of the sampled firms responding to the questionnaire. On the other hand, 2014 exhibits the lowest response rate, with $38 \%$. These response rates indicate a rise in the percentage of responding firms over the years. 
Table 4. Response Status (Sensitivity) of Sampled Firms by Years.

\begin{tabular}{ccccccc}
\hline \multirow{2}{*}{ Year } & \multicolumn{2}{c}{ RESP $=\mathbf{0}^{*}$} & \multicolumn{2}{c}{ RESP $=\mathbf{1}^{*}$} & \multicolumn{2}{c}{ Total } \\
\cline { 2 - 7 } & $\mathbf{N}$ & Percentage & $\mathbf{N}$ & Percentage & $\mathbf{N}$ & Percentage \\
\hline 2014 & 52 & 61.9 & 32 & 38.1 & 84 & 100 \\
2015 & 47 & 55.95 & 37 & 44.05 & 84 & 100 \\
2016 & 46 & 54.76 & 38 & 45.24 & 84 & 100 \\
Total & 145 & 57.54 & 107 & 42.46 & 252 & 100 \\
\hline
\end{tabular}

* RESP is a binary variable which is equal to 1 if the firm responded to the questionnaire and 0 otherwise. $\mathrm{N}$ represents the number of observations.

Table 5 presents the distribution of the response rates of the sampled firms by sectors and years. A closer look at Table 5 shows that with the exception of the information technology sector (which was represented by only one firm), firms from financials sector exhibited the highest response rate $(60.61 \%)$, followed by firms from the utilities (50.00\%) and industrials (45.10) sectors, respectively. The average response rates of remaining sectors are lower than the average rate of full sample for the entire sampled period, and none of the firms from the energy and healthcare sectors responded to the questionnaire in all 3 years. It is an interesting finding that the financials sector, which is a less carbon-intensive sector, exhibited the highest tendency to respond to the CDP questionnaire. Table 5 also shows that the responding rates of four sectors (consumer discretionary, consumer staples, financials and industrials) exhibited an increase in 2016 compared to 2014, while only the response rate of the materials sector showed a decrease.

Table 5. Breakdown of Response Status (Sensitivity) of Sampled Firms by Sectors.

\begin{tabular}{|c|c|c|c|c|c|c|c|}
\hline \multirow{2}{*}{ GICS Sector } & \multirow{2}{*}{ Year } & \multicolumn{2}{|c|}{ RESP $=0$ * } & \multicolumn{2}{|c|}{ RESP $=1$ * } & \multicolumn{2}{|r|}{ Total } \\
\hline & & $\mathbf{N}$ & Percentage & $\mathbf{N}$ & Percentage & $\mathbf{N}$ & Percentage \\
\hline \multirow{4}{*}{ Consumer Discretionary } & 2014 & 10 & 62.50 & 6 & 37.50 & 16 & 100 \\
\hline & 2015 & 10 & 62.50 & 6 & 37.50 & 16 & 100 \\
\hline & 2016 & 9 & 56.25 & 7 & 43.75 & 16 & 100 \\
\hline & Total & 29 & 60.42 & 19 & 39.58 & 48 & 100 \\
\hline \multirow{4}{*}{ Consumer Staples } & 2014 & 7 & 70.00 & 3 & 30.00 & 10 & 100 \\
\hline & 2015 & 6 & 60.00 & 4 & 40.00 & 10 & 100 \\
\hline & 2016 & 6 & 60.00 & 4 & 40.00 & 10 & 100 \\
\hline & Total & 19 & 63.33 & 11 & 36.67 & 30 & 100 \\
\hline \multirow{4}{*}{ Energy } & 2014 & 2 & 100.00 & 0 & 0 & 2 & 100 \\
\hline & 2015 & 2 & 100.00 & 0 & 0 & 2 & 100 \\
\hline & 2016 & 2 & 100.00 & 0 & 0 & 2 & 100 \\
\hline & Total & 6 & 100.00 & 0 & 0 & 2 & 100 \\
\hline \multirow{4}{*}{ Financials } & 2014 & 6 & 54.55 & 5 & 45.45 & 11 & 100 \\
\hline & 2015 & 4 & 36.34 & 7 & 63.64 & 11 & 100 \\
\hline & 2016 & 3 & 27.27 & 8 & 72.73 & 11 & 100 \\
\hline & Total & 13 & 39.39 & 20 & 60.61 & 33 & 100 \\
\hline \multirow{4}{*}{ Healthcare } & 2014 & 1 & 100.00 & 0 & 0 & 1 & 100 \\
\hline & 2015 & 1 & 100.00 & 0 & 0 & 1 & 100 \\
\hline & 2016 & 1 & 100.00 & 0 & 0 & 1 & 100 \\
\hline & Total & 3 & 100.00 & 0 & 0 & 3 & 100 \\
\hline \multirow{4}{*}{ Industrials } & 2014 & 11 & 64.71 & 6 & 35.29 & 17 & 100 \\
\hline & 2015 & 8 & 47.06 & 9 & 52.94 & 17 & 100 \\
\hline & 2016 & 9 & 52.94 & 8 & 47.06 & 17 & 100 \\
\hline & Total & 28 & 54.90 & 23 & 45.10 & 51 & 100 \\
\hline
\end{tabular}


Table 5. Cont.

\begin{tabular}{cccccccc}
\hline \multirow{2}{*}{ GICS Sector } & \multirow{2}{*}{ Year } & \multicolumn{2}{c}{ RESP $=\mathbf{0}$} & \multicolumn{2}{c}{ RESP $=\mathbf{1}$} & \multicolumn{2}{c}{ Total } \\
\cline { 3 - 8 } & & $\mathbf{N}$ & Percentage & $\mathbf{N}$ & Percentage & N & Percentage \\
\hline \multirow{3}{*}{ Information Technology } & 2014 & 0 & 0 & 1 & 100.00 & 1 & 100 \\
& 2015 & 0 & 0 & 1 & 100.00 & 1 & 100 \\
& 2016 & 0 & 0 & 1 & 100.00 & 1 & 100 \\
& Total & 0 & 0 & 3 & 100.00 & 3 & 100 \\
\hline \multirow{3}{*}{ Materials } & 2014 & 12 & 60.00 & 8 & 40.00 & 20 & 100 \\
& 2015 & 13 & 65.00 & 7 & 35.00 & 20 & 100 \\
& 2016 & 13 & 65.00 & 7 & 35.00 & 20 & 100 \\
& Total & 38 & 63.33 & 22 & 36.67 & 60 & 100 \\
\hline \multirow{3}{*}{ Uelecommunication Services } & 2014 & 1 & 0.50 & 1 & 0.50 & 2 & 100 \\
& 2015 & 1 & 0.50 & 1 & 0.50 & 2 & 100 \\
& 2016 & 1 & 0.50 & 1 & 0.50 & 2 & 100 \\
& Total & 3 & 0.50 & 3 & 0.50 & 6 & 100 \\
\hline \multirow{2}{*}{ Utilities } & 2014 & 2 & 0.50 & 2 & 0.50 & 4 & 100 \\
& 2015 & 2 & 0.50 & 2 & 0.50 & 4 & 100 \\
& 2016 & 2 & 0.50 & 2 & 0.50 & 4 & 100 \\
& Total & 6 & 0.50 & 6 & 0.50 & 12 & 100 \\
\hline
\end{tabular}

${ }^{*}$ RESP is a binary variable which is equal to 1 if the firm responded to the questionnaire and 0 otherwise. N represents the number of observations.

Table 6 shows the transparence tendency of the sampled firms. As shown in Table 6, for the entire period, the average percentage of the firms which responded to the questionnaire and allowed CDP to disclose their responses to the public is 30.96 which is lower than the average response rate. By comparing Tables 4 and 6, it can be determined that among the firms which responded to the questionnaire, 11 firms in 2014 and 9 firms both in 2015 and in 2016 did not allow the CDP to disclose their responses to the public. On the other hand, in parallel with the response rate, the disclosure rate which was 25\% in 2014, 33.33\% in 2015 and 34.52 in 2016, showed an increasing trend.

Table 6. Permission Status (Transparency) of Sampled Firms by Years.

\begin{tabular}{ccccccc}
\hline \multirow{2}{*}{ Year } & \multicolumn{2}{c}{ DISC $=\mathbf{0}^{*}$} & \multicolumn{2}{c}{ DISC $=\mathbf{1}^{*}$} & \multicolumn{2}{c}{ Total } \\
\cline { 2 - 7 } & $\mathbf{N}$ & Percentage & $\mathbf{N}$ & Percentage & N & Percentage \\
\hline 2014 & 63 & 75.00 & 21 & 25.00 & 84 & 100 \\
2015 & 56 & 66.67 & 28 & 33.33 & 84 & 100 \\
2016 & 55 & 65.48 & 29 & 34.52 & 84 & 100 \\
Total & 174 & 69.04 & 78 & 30.96 & 252 & 100 \\
\hline
\end{tabular}

* DISC is a binary variable which is if the firm responded to the questionnaire and allowed the CDP to disclose the response to the public and 0 otherwise. $\mathrm{N}$ represents the number of observations.

Table 7 demonstrates the distribution of the disclosure rates of the sampled firms by sectors and years. According to Table 7, in line with the response rates, firms from financials sector exhibited the highest disclosure rate $(60.61 \%)$. Besides the financials sector, the average disclosure rates of utilities, telecommunication services and consumer discretionary sectors are higher than the average disclosure rate of the full sample for the analyzed period. In contrast, none of the firms from the energy and healthcare sectors disclosed their GHG emissions to the public for the entire sampled period. On the other hand, in line with response rates, the disclosure rates of four sectors (consumer discretionary, consumer staples, financials and industrials) increased in 2016 compared to 2014 while the response rate of materials sector decreased. 
Table 7. Breakdown of Permission Status (Transparency) of Sampled Firms by Years.

\begin{tabular}{|c|c|c|c|c|c|c|c|}
\hline \multirow{2}{*}{ GICS Sector } & \multirow{2}{*}{ Year } & \multicolumn{2}{|c|}{ DISC $=0$ * } & \multicolumn{2}{|c|}{ DISC $=1$ * } & \multicolumn{2}{|r|}{ Total } \\
\hline & & $\mathbf{N}$ & Percentage & $\mathbf{N}$ & Percentage & $\mathbf{N}$ & Percentage \\
\hline \multirow{4}{*}{ Consumer Discretionary } & 2014 & 12 & 75.00 & 4 & 25.00 & 16 & 100 \\
\hline & 2015 & 11 & 62.50 & 5 & 31.25 & 16 & 100 \\
\hline & 2016 & 10 & 56.25 & 6 & 37.50 & 16 & 100 \\
\hline & Total & 33 & 68.75 & 15 & 31.25 & 48 & 100 \\
\hline \multirow{4}{*}{ Consumer Staples } & 2014 & 8 & 80.00 & 2 & 20.00 & 10 & 100 \\
\hline & 2015 & 7 & 70.00 & 3 & 30.00 & 10 & 100 \\
\hline & 2016 & 7 & 70.00 & 3 & 30.00 & 10 & 100 \\
\hline & Total & 22 & 73.33 & 8 & 26.67 & 30 & 100 \\
\hline \multirow{4}{*}{ Energy } & 2014 & 2 & 100.00 & 0 & 0 & 2 & 100 \\
\hline & 2015 & 2 & 100.00 & 0 & 0 & 2 & 100 \\
\hline & 2016 & 2 & 100.00 & 0 & 0 & 2 & 100 \\
\hline & Total & 6 & 100.00 & 0 & 0 & 6 & 100 \\
\hline \multirow{4}{*}{ Financials } & 2014 & 6 & 54.55 & 5 & 45.45 & 11 & 100 \\
\hline & 2015 & 5 & 45.45 & 6 & 54.55 & 11 & 100 \\
\hline & 2016 & 4 & 36.37 & 7 & 63.63 & 11 & 100 \\
\hline & Total & 15 & 45.45 & 18 & 54.55 & 33 & 100 \\
\hline \multirow{4}{*}{ Healthcare } & 2014 & 1 & 100.00 & 0 & 0 & 1 & 100 \\
\hline & 2015 & 1 & 100.00 & 0 & 0 & 1 & 100 \\
\hline & 2016 & 1 & 100.00 & 0 & 0 & 1 & 100 \\
\hline & Total & 3 & 100.00 & 0 & 0 & 1 & 100 \\
\hline \multirow{4}{*}{ Industrials } & 2014 & 13 & 76.47 & 4 & 23.53 & 17 & 100 \\
\hline & 2015 & 12 & 70.59 & 5 & 29.41 & 17 & 100 \\
\hline & 2016 & 12 & 70.59 & 5 & 29.41 & 17 & 100 \\
\hline & Total & 37 & 72.55 & 14 & 27.45 & 51 & 100 \\
\hline \multirow{4}{*}{ Information Technology } & 2014 & 1 & 100.00 & 0 & 0 & 1 & 100 \\
\hline & 2015 & 1 & 100.00 & 0 & 0 & 1 & 100 \\
\hline & 2016 & 1 & 100.00 & 0 & 0 & 1 & 100 \\
\hline & Total & 3 & 100.00 & 0 & 0 & 3 & 100 \\
\hline \multirow{4}{*}{ Materials } & 2014 & 16 & 80.00 & 4 & 20.00 & 20 & 100 \\
\hline & 2015 & 15 & 75.00 & 5 & 25.00 & 20 & 100 \\
\hline & 2016 & 15 & 75.00 & 5 & 25.00 & 20 & 100 \\
\hline & Total & 46 & 76.67 & 14 & 23.33 & 60 & 100 \\
\hline \multirow{4}{*}{ Telecommunication Services } & 2014 & 1 & 0.50 & 1 & 0.50 & 2 & 100 \\
\hline & 2015 & 1 & 0.50 & 1 & 0.50 & 2 & 100 \\
\hline & 2016 & 1 & 0.50 & 1 & 0.50 & 2 & 100 \\
\hline & Total & 3 & 0.50 & 3 & 0.50 & 6 & 100 \\
\hline \multirow{4}{*}{ Utilities } & 2014 & 2 & 0.50 & 2 & 0.50 & 4 & 100 \\
\hline & 2015 & 2 & 0.50 & 2 & 0.50 & 4 & 100 \\
\hline & 2016 & 2 & 0.50 & 2 & 0.50 & 4 & 100 \\
\hline & Total & 6 & 0.50 & 6 & 0.50 & 12 & 100 \\
\hline
\end{tabular}

* DISC is a binary variable which is if the firm responded to the questionnaire and allowed the CDP to disclose the response to the public and 0 otherwise. $\mathrm{N}$ represents the number of observations.

Table 8 presents the number and percentage of sampled firms operating in carbon-intensive sectors and firms that operate in less carbon-intensive sectors. According to Table 8, approximately $58 \%$ of sampled firms operate in carbon-intensive sectors. 
Table 8. Carbon Impact of Sampled Firms.

\begin{tabular}{ccc}
\hline Industry & Number of Firms & Percentage (\%) \\
\hline Carbon-intensive industries & 49 & 58.33 \\
Less Carbon-intensive industries & 35 & 41.67 \\
Total & 84 & 100 \\
\hline
\end{tabular}

The results of the descriptive analysis of continuous variable are reported in Table 9. According to Table 9, the mean value of sampled firms' total assets, which is a proxy of firm size, is 27,325.95 (in TRY $\mathrm{mn}$ ) for the sampled period. This means that our sample includes relatively larger firms. We can make an inference from this table that during the sample period, the profitability of sampled Turkish firms is quite low with a mean of $3 \%$ in terms of ROA. In spite of the low profitability average, financial leverage level is higher than expected. This can be a sign that sample firms have high financial risk levels. The institutional ownership proportion is about at 0.57 level on average, and this means that more than half of the shareholders of the sampled firms are institutions. With regard to board size, we can state that Turkish firms have smaller boards compared to other countries. The average board size is 13.99 in Germany, 14.34 in Austria, 15.50 in Hungary, 12.72 in Italy, 12.49 in Spain, while in Turkey it is just 8.91 [114]. Finally, the mean value of the percentage of independent directors on the board is 0.3 which implies that the majority of the sampled firms' boards consist of dependent directors.

Table 9. Descriptive Statistics for Continuous Variables $(\mathrm{N}=252)$.

\begin{tabular}{cccccc}
\hline Variables & Mean & Std. Dev. & Minimum & Median & Maximum \\
\hline TA (in TRY mn) & $27,325.95$ & $69,839.91$ & 55,11106 & $3,435.97$ & $373,820.3$ \\
ROA & 0.03 & 0.19 & -0.73 & 0.025 & 2.63 \\
LEV & 0.62 & 0.35 & 0.00 & 0.61 & 2.85 \\
INSTS & 0.57 & 0.24 & 0.00 & 0.63 & 0.95 \\
MtB & 1.41 & 0.85 & -32.92 & 1.09 & 13.20 \\
BSIZE & 8.91 & 2.49 & 3.00 & 9.00 & 18.00 \\
INDP & 0.30 & 0.09 & 0 & 0.33 & 1.00 \\
\hline
\end{tabular}

$\mathrm{N}$ represents the number of observations. Please find the definitions of variables in Table 3.

Table 10 shows the mean values of continuous variables by sector. According to Table 10, the financial sector represents the largest sector in terms of total assets, followed by telecommunication services and energy sectors. The highest profitability (ROA) ratio is $9.8 \%$ and belongs to the materials sector, while consumer discretionary and utilities sectors have negative ROA. As expected, the most leveraged sector is financials which is followed by consumer discretionary and information technology sectors, respectively. On the other hand, healthcare, energy and materials sectors have the lowest leveraged ratios: $17.60 \%, 40.80 \%$ and $40.27 \%$ respectively. With respect to the institutional ownership, the average proportion of institutional shareholders in equity is highest in the healthcare and telecommunication services sectors, $78.40 \%$ and 74.80 respectively. Consumer staples sector has the highest market-to-book ratio $(3,558)$ and is followed by the telecommunication services sector $(3,008)$ which can be interpreted as firms that operate in these sectors have a good reputation and potential for development [115]. In terms of the number of directors on the board, the largest boards belong to energy, financials and telecommunication services. Finally, for the last variable, board independence, the highest percentages of independent directors on the board belong to telecommunication services, materials and energy sectors, with $38.10 \%, 33.20 \%$ and $32.50 \%$ respectively. 
Table 10. Descriptive Statistics by Sectors.

\begin{tabular}{cccccccc}
\hline GICS Sector & TA (in TRY mn) & ROA & LEV & INSTS & MtB & BSIZE & INDP \\
\hline Consumer Discretionary & 3009.979 & -0.018 & 0.821 & 0.671 & -0.164 & 8.896 & 0.282 \\
Consumer Staples & 5927.867 & 0.021 & 0.549 & 0.560 & 3.558 & 9.367 & 0.302 \\
Energy & $14,560.167$ & 0.041 & 0.408 & 0.566 & 0.895 & 10.667 & 0.325 \\
Financials & $164,222.970$ & 0.018 & 0.832 & 0.518 & 0.955 & 10.3934 & 0.267 \\
Healthcare & 3542.000 & 0.018 & 0.176 & 0.784 & 0.550 & 7.000 & 0.286 \\
Industrials & $13,160.235$ & 0.042 & 0.607 & 0.513 & 1.817 & 9.039 & 0.322 \\
Information Technology & 1209.667 & 0.017 & 0.640 & 0.632 & 1.391 & 7.000 & 0.286 \\
Materials & 2722.416 & 0.098 & 0.427 & 0.547 & 1.390 & 7.800 & 0.332 \\
Telecommunication Services & $25,663.000$ & 0.052 & 0.600 & 0.748 & 3.008 & 9.500 & 0.381 \\
Utilities & 4529.500 & -0.019 & 0.702 & 0.687 & 1.721 & 8.667 & 0.273 \\
\hline
\end{tabular}

Please find the definitions of variables in Table 3.

\subsection{Correlation Analysis}

Table 11 presents the Pearson bivariate correlation coefficients for the variables used in the study. According to the results of Pearson correlation analysis, our two dependent variables, RESP and DISC, are significantly and positively correlated to the TA, with the correlation coefficients of 0.131 and $0.156(p<0.05)$, respectively. This result is in line with our expectations and indicates that larger firms are more likely to respond to CDP questionnaires and to disclose their GHG emissions to the public. Besides that, the correlation between DISC and INSTS is positive and statistically significant $(0.139 ; p<0.05)$, indicating that firms with a higher share of institutional investors tend to disclose GHG emissions to the public. On the other hand, the remaining independent variables are not statistically correlated to the RESP and DISC, contrary to our expectations. Finally, the largest correlation among independent variables involves CISs and TA $(0.3613 ; p<0.1)$ and the relatively low correlation coefficients among whole independent variables presents that multicollinearity may not be a threat in our analysis.

Table 11. Pearson Correlation Matrix.

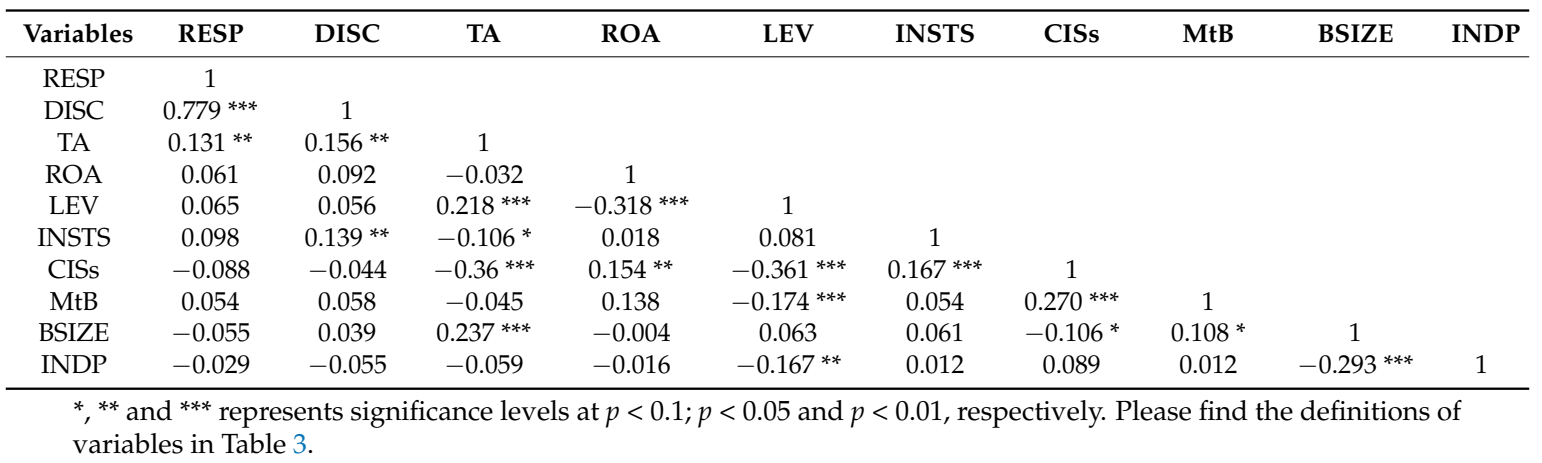

\subsection{Regression Results}

Table 12 reports the results of logistic regression tests of RESP and DISC. The Pseudo- $\mathrm{R}^{2}$ statistics for the models are very low, $4.4 \%$ for the first model and $5.3 \%$ for the second model. However, it should be noted that the interpretation of pseudo $R^{2}$ is not exactly the same with $R^{2}$ used in linear regression analysis, which reports the proportional variance in the dependent variable that is "explained" by the independent variables, as pseudo $\mathrm{R}^{2}$ provides only a rough approximation of the amount of variance explain and it can be used as an approximate measure of the goodness of fit of the estimated categorical logistic regression model [116,117]. 
Table 12. Logistic Regression Test Results.

\begin{tabular}{|c|c|c|c|c|c|c|c|c|c|c|}
\hline & \multicolumn{5}{|c|}{ MODEL 1 (Dependent Variable: RESP) } & \multicolumn{5}{|c|}{ MODEL 2 (Dependent Variable: DISC) } \\
\hline Independent Variables & Exp. Sign & coeff. & Std. Err. & $z$-value & $p$-value & Exp. Sign & coeff. & Std. Err. & $z$-value & $p$-value \\
\hline TA & + & 4.16 & 0.23 & $1.85 *$ & 0.065 & + & 5.05 & 2.22 & $2.28 * *$ & 0.023 \\
\hline ROA & + & 1.04 & 0.81 & 1.29 & 0.198 & + & 1.39 & 0.77 & $1.81 *$ & 0.070 \\
\hline INSTS & + & 1.15 & 0.61 & $1.87 *$ & 0.061 & + & 1.62 & 0.72 & $2.24 * *$ & 0.025 \\
\hline CISs & + & -0.40 & 0.32 & -1.25 & 0.212 & + & -0.11 & 0.36 & -0.30 & 0.764 \\
\hline $\mathrm{MtB}$ & $+/-$ & 0.05 & 0.03 & $1.68 *$ & 0.092 & $+1-$ & 0.04 & 0.31 & 1.32 & 0.188 \\
\hline INDP & + & -1.07 & 1.38 & -0.77 & 0.439 & + & -1.23 & 1.62 & -0.76 & 0.447 \\
\hline Log pseudolikelihood & & & 164.143 & & & & & 147.555 & & \\
\hline LR (8) & & & 15.308 & & & & & 16.724 & & \\
\hline Wald chi-square & & & 13.93 & & & & & 14.44 & & \\
\hline Prob $>$ chi 2 & & & 0.0835 & & & & & 0.0536 & & \\
\hline McFadden's pseudo $\mathrm{R}^{2}$ & & & 0.044 & & & & & 0.053 & & \\
\hline
\end{tabular}

According to Table 12, the results of the first model show that TA, INSTS, MtB and BSIZE have statistically significant impacts on RESP $[70,118,119]$. As expected, TA, INSTS and MtB are positively related to RESP. This result is consistent with References [31,34] and implies that firms with higher total assets, with higher institutional shareholdings and with higher market value are more likely to respond to CDP questionnaires. On the other hand, contrary to our expectations, a negative relationship between BSIZE and RESP, which means that firms with smaller boards are more likely to respond CDP questionnaire, is detected. This negative relationship can be expounded with two different perspectives. The first one is that larger boards can be beneficial for monitoring capacity but may cause more communication problems and long decision-making processes $[7,120,121]$. The second perspective is about terms of expertise. Expertness diversity is higher in larger boards but this may also cause a lack of financial or accounting background and, therefore, less negotiation power [122]. Besides, it can be determined as participating and responding to the CDP questionnaires cannot be explained by ROA, LEV, CISs and INDP under a statistically significant manner. This finding is quite interesting, especially in terms of CISs, as we expected that firms that operate in carbon-intensive industries are more likely to respond to the CDP questionnaire. The fact that in our sample, the highest response rate to the CDP questionnaire belongs to the financials sector, which is a less carbon-intensive sector, may provide a possible explanation for this insignificant relationship between RESP and CISs.

Similar to the sensitivity model, in the transparency model both TA and INSTS have a significant and positive relation with DISC. In addition to TA and INSTS, disclosure behavior of firms is also positively affected by ROA. Legitimacy theory outlines the accountability and visibility of firms. It is obvious that external monitoring is more intensive for larger firms compared to smaller firms [34]. Larger firms are analyzed not only by managers and by shareholders but also by media, public and governments. This pressure may have encouraged firms to disclose their GHG emission to the public [118]. Another pressure may have come from institutional investors' calls for more transparent disclosures [29]. In line with these inferences, the coefficients of the variables demonstrate that TA and INSTS have a notable influence on DISC in comparison to ROA. These empirical findings are partially consistent with Reference [11,12]. Notwithstanding any statistically significant effects of LEV, CISs, $\mathrm{MtB}, \mathrm{BSIZE}$ and INDP on DISC are detected for confidence levels. Therefore, these variables cannot be considered as the determinants of voluntary GHG disclosure in Turkey's case. Same as the sensitivity model, in the tendency model, it cannot be said that carbon-intensive industry firms tend to disclose their GHG activities and questionnaire results to the public. The insignificant relationship between DISC and CISs can be explained by the dominance of the financial sector in our sample. Our findings with regard to the corporate governance variables allows us to affirm that communication problems, 
long decision-making processes and superiority of dependent directors over independent directors can be the main reasons behind the rejection of firms to disclose their GHG activities.

Table 13 summarizes the results of logistic regression analysis for all our hypotheses.

Table 13. Summary of Test Results.

\begin{tabular}{cccc}
\hline Hypothesis & Result & Hypothesis & Result \\
\hline $\mathrm{H} 1 \mathrm{a}$ & Cannot be Rejected & $\mathrm{H} 5 \mathrm{a}$ & Rejected \\
$\mathrm{H} 1 \mathrm{~b}$ & Cannot be Rejected & $\mathrm{H} 5 \mathrm{~b}$ & Rejected \\
$\mathrm{H} 2 \mathrm{a}$ & Rejected & $\mathrm{H} 6 \mathrm{a}$ & Cannot be Rejected \\
$\mathrm{H} 2 \mathrm{~b}$ & Cannot be Rejected & $\mathrm{H} 6 \mathrm{~b}$ & Rejected \\
$\mathrm{H} 3 \mathrm{a}$ & Rejected & $\mathrm{H7a}$ & Rejected \\
$\mathrm{H} 3 \mathrm{~b}$ & Rejected & $\mathrm{H} 7 \mathrm{~b}$ & Rejected \\
$\mathrm{H} 4 \mathrm{a}$ & Cannot be Rejected & $\mathrm{H} 8 \mathrm{a}$ & Rejected \\
$\mathrm{H} 4 \mathrm{~b}$ & Cannot be Rejected & $\mathrm{H} 8 \mathrm{~b}$ & Rejected \\
\hline
\end{tabular}

Furthermore, we conducted probit regression analysis, which is also a proper regression method where the dependent variable is a dummy variable, to run robustness checks for our two models (see Appendix A). The results are consistent with our main results presented in Table 12.

\section{Conclusions}

GHG emissions have been regarded as the main cause of global warming, which represents one of the most serious environmental issues that the world is faced with. In this sense, measuring and disclosing GHG emission performance has been attracting special attention. This attention is not only for humans, governments or nongovernment initiatives, but it is also an important phenomenon for companies. Due to their operations and their influential positions, companies have to take initiative for providing information to the public about environmental issues and reducing GHG emissions for a sustainable world. In this study, we attempted to identify the determinants of GHG disclosures of Turkish firms on the basis of a CDP survey that collects annual information related to GHG emissions, climate change risks/opportunities and management strategies of companies all over the world. Based on a sample of 84 firms which were targeted by the CDP in the years of 2014, 2015 and 2016, we analyzed the factors affecting "sensitiveness tendency", which refers to the respond behavior, and "transparence tendency", which presents the disclosure behavior of Turkish listed firms.

Findings of the study emphasize that, in Turkey, both the number of firms responding to the CDP questionnaire and the number of firms disclosing their GHG emissions to the public have increased over the years. On the other hand, it is an interesting finding that the financials sector had the highest response and disclosure rates in all 3 years analyzed.

With regard to the possible determinants of GHG disclosure, our results indicate that only firm size and institutional ownership are significantly and positively related to both the response and disclosure behavior of Turkish firms. These results are in line with our expectations and confirm that larger firms and firms with higher institutional shareholdings are more likely to respond to the CDP questionnaire and to disclose their GHG emissions to the public. Besides firm size and institutional ownership, we found that the ratio of market-to-book value also positively influences the likelihood of responding to the CDP questionnaire. If we consider the market-to-book ratio as a sign of reputation, this result can be interpreted as more reputable firms are more likely to respond to the CDP in order to protect their reputation.

Furthermore, our test results show that besides firm size and institutional ownership, profitability is also positively related to the disclosure behavior of firms, implying that more profitable firms are more likely to disclose their GHG emissions to the public. This result is also consistent with our expectations. These finding can be compounded as firms that earn high profits tend to demonstrate that that they do not harm the environment while performing their activities. 
On the other hand, for leverage, industrial membership and board independence, our results indicate that these variables are unrelated to both the response and disclosure behavior of sampled firms. This result may stem from the composition of our sample.

This study contributes to the existing literature by providing insights on GHG disclosure from a developing country, Turkey, and by considering the effects of both financial and corporate governance variables on the disclosure behavior of firms. Furthermore, the findings may be useful for corporate stakeholders and policy-makers. In this sense, the regulatory bodies may consider enacting compulsory GHG reporting for high carbon-impact sectors, considering that industry membership does not affect the GHG disclosure of our sampled firms.

This study is subject to several limitations. First, the primary data related to GHG disclosure relies on CDP survey, though firms can use a variety of channels such as annual reports and/or sustainability reports, to disclose GHG emissions. Second, the data used in this study covers a 3-year period. In this framework, future research could investigate the determinants of GHG disclosure by using a longer data set and also by considering other communication channels that firms can use to disclose GHG emissions.

Author Contributions: In this paper, contributions of authors are given as follows; “conceptualization, H.E.A. and S.C.; methodology, S.C. and H.E.A.; investigation, H.E.A.; data curation, H.E.A. and S.C., writing-review and editing, H.E.A. and S.C.

Funding: This research received no external funding.

Conflicts of Interest: The authors declare no conflict of interest.

\section{Appendix A.}

Table A1. Probit Regression Test Results.

\begin{tabular}{|c|c|c|c|c|c|c|c|c|c|c|}
\hline Independent Variables & \multicolumn{5}{|c|}{ MODEL 1 (Dependent Variable: RESP) } & \multicolumn{5}{|c|}{ MODEL 2 (Dependent Variable: DISC) } \\
\hline TA & + & 2.52 & 1.38 & $1.88 *$ & 0.061 & + & 3.00 & 1.32 & $2.27^{* *}$ & 0.023 \\
\hline LEV & $+1-$ & 0.13 & 0.26 & 0.49 & 0.623 & $+/-$ & 0.14 & 0.25 & 0.56 & 0.576 \\
\hline INSTS & + & 0.68 & 0.36 & $1.88^{*}$ & 0.060 & + & 0.91 & 0.40 & $2.27^{* *}$ & 0.023 \\
\hline CISs & + & -0.25 & 0.20 & -1.28 & 0.200 & + & -0.09 & 0.21 & -0.42 & 0.674 \\
\hline INDP & + & -0.62 & 0.85 & -0.73 & 0.466 & + & -0.65 & 0.92 & -0.70 & 0.482 \\
\hline Log pseudolikelihood & & & 164.190 & & & & & 147.668 & & \\
\hline LR $(8)$ & & & 15.214 & & & & & 16.498 & & \\
\hline Wald chi-square & & & 14.96 & & & & & 16.17 & & \\
\hline Prob $>$ chi 2 & & & 0.0600 & & & & & 0.0400 & & \\
\hline
\end{tabular}

\section{References}

1. Peng, J.; Sun, J.; Luo, R. Corporate voluntary carbon information disclosure: Evidence from China's listed companies. World Economy 2015, 38, 91-109. [CrossRef]

2. Eleftheriadis, I.M.; Anagnostopoulou, E.G. Relationship between corporate climate change disclosures and firm factors. Bus. Strategy Environ. 2015, 24, 780-789. [CrossRef]

3. Haque, S.; Deegan, C.; Inglis, R. Demand for, and impediments to, the disclosure of information about climate change-related corporate governance practices. Account. Bus. Res. 2016, 46, 620-664. [CrossRef]

4. Pellegrino, C.; Lodhia, S. Climate change accounting and the Australian mining industry: Exploring the links between corporate disclosure and the generation of legitimacy. J. Clean. Prod. 2012, 36, 68-82. [CrossRef]

5. Höijer, B. Emotional anchoring and objectification in the media reporting on climate change. Public Underst. Sci. 2010, 19, 717-731. [CrossRef] [PubMed] 
6. Romar, E. Snapshots of the future: Darfur, Katrina, And Maple Sugar (climate change, the less well-off and business ethics). J. Bus. Ethics 2009, 85, 121-132. [CrossRef]

7. Amran, A.; Periasamy, V.; Zulkafli, A.H. Determinants of climate change disclosure by developed and emerging countries in Asia Pacific. J. Sustain. Dev. 2014, 22, 188-204. [CrossRef]

8. IPCC. Climate Change 2014: Synthesis Report. Contribution of Working Groups I, II and III to the Fifth Assessment Report of the Intergovernmental Panel on Climate Change; Pachauri, R.K., Meyer, L.A., Eds.; IPCC: Geneva, Switzerland, 2014; 151p.

9. IPCC. Climate Change 2014: Impacts, Adaptation, and Vulnerability. Summaries, Frequently Asked Questions, and Cross-Chapter Boxes; A Contribution of Working Group II to the Fifth Assessment Report of the Intergovernmental Panel on Climate Change; Field, C.B., Barros, V.R., Dokken, D.J., Mach, K.J., Mastrandrea, M.D., Bilir, T.E., Chatterjee, M., Ebi, K.L., Estrada, Y.O., Genova, R.C., et al., Eds.; World Meteorological Organization: Geneva, Switzerland, 2014; 190p.

10. Beggs, P.J. Impacts of climate change on aeroallergens: Past and future. Clin. Exp. Allergy 2004, 34, 1507-1513. [CrossRef] [PubMed]

11. Halkos, G.; Skouloudis, A. Exploring the Current Status and Key Determinants of Corporate Disclosure on Climate Change: Evidence from the Greek business sector. Environ. Sci. Policy 2016, 56, 22-31. [CrossRef]

12. Luo, L.; Lan, Y.C.; Tang, Q. Corporate incentives to disclose carbon information: Evidence from the CDP Global 500 Report. J. Int. Financ. Manag. Account. 2012, 23, 93-120. [CrossRef]

13. Lai, J.H. Mandatory reporting of greenhouse gas emissions from buildings: Stakeholders' opinions in Hong Kong. Energy Policy 2014, 75, 278-288. [CrossRef]

14. Cubasch, U.; Wuebbles, D.; Chen, D.; Facchini, M.C.; Frame, D.; Mahowald, N.; Winther, J.G. Introduction. In Climate Change 2013: The Physical Science Basis; Contribution of Working Group I to the Fifth Assessment Report of the Intergovernmental Panel on Climate Change; Stocker, T.F., Qin, D., Plattner, G.K., Tignor, M., Allen, S.K., Boschung, J., Nauels, A., Xia, Y., Bex, V., Midgley, P.M., Eds.; Cambridge University Press: Cambridge, UK; New York, NY, USA, 2013; pp. 119-158.

15. IPCC. Climate Change 2007: The Physical Science Basis; Contribution of Working Group I to the Fourth Assessment Report of the Intergovernmental Panel on Climate Change; Solomon, S., Qin, D., Manning, M., Chen, Z., Marquis, M., Averyt, K.B., Tignor, M., Miller, H.L., Eds.; Cambridge University Press: Cambridge, UK; New York, NY, USA, 2007; 996p.

16. Chalikias, M.; Ntanos, S. Countries clustering with respect to carbon dioxide emissions by using the iea database. In Proceedings of the 7th International Conference on Information and Communication Technologies in Agriculture, Food and Environment (HAICTA 2015), Kavala, Greece, 17-20 September 2015; pp. 347-351. Available online: http:// ceur-ws.org/Vol-1498/HAICTA_2015_paper41.pdf (accessed on 5 September 2018).

17. Ntanos, S.; Skordoulis, M.; Kyriakopoulos, G.; Arabatzis, G.; Chalikias, M.; Galatsidas, S.; Batzios, A.; Katsarou, A. Renewable energy and economic growth: Evidence from European countries. Sustainability 2018, 10, 2626. [CrossRef]

18. Ntanos, S.; Arabatzis, G.; Milioris, K.; Chalikias, M.; Lalou, P. Energy consumption and $\mathrm{CO}_{2}$ emissions on a global level. In Proceedings of the 4th International Conference: Quantitative and Qualitative Methodologies in the Economic and Administrative Sciences (I.C.Q.Q.M.E.A.S. 2015), Egaleo, Greece, 21-22 May 2015; pp. 251-260. Available online: http://econferences.teiath.gr/index.php/ICQQMEAS/ ICQQMEAS2015/paper/viewFile/137/134 (accessed on 5 September 2018).

19. Green, W.; Zhou, S. An international examination of assurance practices on carbon emissions disclosures. Aust. Account. Rev. 2013, 23, 54-66. [CrossRef]

20. Bebbington, J.; Larrinaga-Gonzalez, C. Carbon trading: Accounting and reporting issues. Eur. Account. Rev. 2008, 17, 697-717. [CrossRef]

21. IPCC. Climate Change 2013: The Physical Science Basis; Contribution of Working Group I to the Fifth Assessment Report of the Intergovernmental Panel on Climate Change; Stocker, T.F., Qin, D., Plattner, G.K., Tignor, M., Allen, S.K., Boschung, J., Nauels, A., Xia, Y., Bex, V., Midgley, P.M., Eds.; Cambridge University Press: Cambridge, UK; New York, NY, USA, 2013; 1535p.

22. Guenther, E.; Guenther, T.; Schiemann, F.; Weber, G. Stakeholder relevance for reporting: Explanatory factors of carbon disclosure. Bus. Soc. 2016, 55, 361-397. [CrossRef] 
23. Kolk, A.; Levy, D.; Pinkse, J. Corporate responses in an emerging climate regime: The institutionalization and commensuration of carbon disclosure. Eur. Account. Rev. 2008, 17, 719-745. [CrossRef]

24. Haque, S.; Deegan, C. Corporate climate change-related governance practices and related disclosures: Evidence from Australia. Aust. Account. Rev. 2010, 20, 317-333. [CrossRef]

25. Sullivan, R.; Gouldson, A. Ten years of corporate action on climate change: What do we have to show for it? Energy Policy 2013, 60, 733-740. [CrossRef]

26. Depoers, F.; Jeanjean, T.; Jérôme, T. Voluntary disclosure of greenhouse gas emissions: Contrasting the Carbon Disclosure Project and corporate reports. J. Bus. Ethics 2014, 134, 445-461. [CrossRef]

27. Lee, S.Y.; Park, Y.S.; Klassen, R.D. Market responses to firms' voluntary climate change information disclosure and carbon communication. Corp. Soc. Responsib. Environ. Manag. 2015, 22, 1-12. [CrossRef]

28. Kauffmann, C.; Less, C.T.; Teichmann, D. Corporate Greenhouse Gas Emission Reporting; OECD: New York, NY, USA, 2012.

29. Hahn, R.; Reimsbach, D.; Schiemann, F. Organizations, climate change, and transparency: Reviewing the literature on carbon disclosure. Organ. Environ. 2015, 28, 80-102. [CrossRef]

30. KPMG; Global Reporting Initiative. Reporting the Business Implications of Climate Change in Sustainability Reports: A Survey. 2007. Available online: https:/ /www.globalreporting.org/resourcelibrary/Reportingon-the-Business-Implications-of-Climate-Change-in-Sustainability-Reports.pdf (accessed on 15 July 2018).

31. Grauel, J.; Gotthardt, D. The relevance of national contexts for carbon disclosure decisions of stock-listed companies: A multilevel analysis. J. Clean. Prod. 2016, 133, 1204-1217. [CrossRef]

32. Matsumura, E.M.; Prakash, R.; Vera-Muñoz, S.C. Firm-value effects of carbon emissions and carbon disclosures. Account. Rev. 2013, 89, 695-724. [CrossRef]

33. Comyns, B.; Figge, F. Greenhouse gas reporting quality in the oil and gas industry: A longitudinal study using the typology of "search", "experience" and "credence" information. Account. Audit. Account. J. 2015, 28, 403-433. [CrossRef]

34. Ben-Amar, W.; Chang, M.; McIlkenny, P. Board gender diversity and corporate response to sustainability initiatives: Evidence from the Carbon Disclosure Project. J. Bus. Ethics 2017, 142, 369-383. [CrossRef]

35. Cotter, J.; Najah, M.M. Institutional investor influence on global climate change disclosure practices. Aust. J. Manag. 2012, 37, 169-187. [CrossRef]

36. Gökşen, N.S.; Üsdiken, B. Uniformity and diversity in Turkish business groups: Effects of scale and time of founding. Br. J. Manag. 2001, 12, 325-340. [CrossRef]

37. Oba, B.; Ozsoy, Z.; Atakan, S. Power in the boardroom: A study on Turkish family-owned and listed companies. Corp. Gov. Int. J. Bus. Soc. 2010, 10, 603-616. [CrossRef]

38. Arcuri, A. The Rise of a New Superpower: Turkey's Key Role in the World Economy and Energy Market; Springer: New York City, NY, USA, 2013.

39. Uyar, A.; Gungormus, A.H.; Kuzey, C. Impact of the accounting information system on corporate governance: Evidence from Turkish non-listed companies. Australas. Account. Bus. Financ. J. 2017, 11, 9-27. [CrossRef]

40. Demir, V.; Bahadir, O. An Investigation of compliance with international financial reporting standards by listed companies in Turkey. Account. Manag. Inf. Syst. 2014, 13, 4.

41. Jianu, I.; Jianu, I. The told and retold story of Romanian accounting. Account. Manag. Inf. Syst. 2012, 11, 391.

42. Aydın, L. Effects of increasing indigenous coal share in Turkey's electricity generation mix on key economic and environmental indicators: An extended input-output analysis. Energy Explor. Exploit. 2018, 36, 230-245. [CrossRef]

43. Ernstberger, J.; Grüning, M. How do firm and country-level governance mechanisms affect firms' disclosure? J. Account. Public Policy 2013, 32, 50-67. [CrossRef]

44. Allegrini, M.; Greco, G. Corporate boards, audit committees and voluntary disclosure: Evidence from Italian listed companies. J. Manag. Gov. 2013, 17, 187-216. [CrossRef]

45. Cheng, E.C.; Courtenay, S.M. Board composition, regulatory regime and voluntary disclosure. Int. J. Account. 2006, 41, 262-289. [CrossRef]

46. Gul, F.A.; Leung, S. Board leadership, outside directors' expertise and voluntary corporate disclosures. J. Account. Public Policy 2004, 23, 351-379. [CrossRef]

47. Cormier, D.; Lapointe-Antunes, P.; Magnan, M. Does corporate governance enhance the appreciation of mandatory environmental disclosure by financial markets? J. Manag. Gov. 2015, 19, 897-925. [CrossRef] 
48. Iatridis, G.E. Environmental disclosure quality: Evidence on environmental performance, corporate governance and value relevance. Emerg. Mark. Rev. 2013, 14, 55-75. [CrossRef]

49. Arcay, M.R.B.; Vazquez, M.F.M. Corporate characteristics, governance rules and the extent of voluntary disclosure in Spain. Adv. Account. 2005, 21, 299-331. [CrossRef]

50. Michelon, G.; Parbonetti, A. The effect of corporate governance on sustainability disclosure. J. Manag. Gov. 2012, 16, 477-509. [CrossRef]

51. Deegan, C. Introduction: The legitimising effect of social and environmental disclosures: A theoretical foundation. Account. Audit. Account. J. 2002, 15, 282-311. [CrossRef]

52. Luo, L.; Tang, Q. Does voluntary carbon disclosure reflect underlying carbon performance? J. Contemp. Account. Econ. 2014, 10, 191-205. [CrossRef]

53. Hahn, R.; Lülfs, R. Legitimizing negative aspects in gri-oriented sustainability reporting: A Qualitative analysis of corporate disclosure strategies. J. Bus. Ethics 2014, 123, 401-420. [CrossRef]

54. Tang, Q.; Tang, Q.; Luo, L.; Luo, L. Corporate Ecological Transparency: Theories and Empirical Evidence. Asian Rev. Account. 2016, 24, 498-524. [CrossRef]

55. Solomon, A.; Lewis, L. Incentives and disincentives for corporate environmental disclosure. Bus. Strategy Environ. 2002, 11, 154-169. [CrossRef]

56. Ntim, C.G.; Lindop, S.; Thomas, D.A. Corporate governance and risk reporting in South Africa: A study of corporate risk disclosures in the pre-and post-2007/2008 global financial crisis periods. Int. Rev. Financ. Anal. 2013, 30, 363-383. [CrossRef]

57. Cormier, D.; Magnan, M. Corporate environmental disclosure strategies: Determinants, costs and benefits. J. Account. Audit. Financ. 1999, 14, 429-451. [CrossRef]

58. Cormier, D.; Magnan, M.; van Velthoven, B. Environmental disclosure quality in large German companies: Economic incentives, public pressures or institutional conditions? Eur. Account. Rev. 2005, 14, 3-39. [CrossRef]

59. Campbell, K.; Sefcik, S.E.; Soderstrom, N.S. Disclosure of private information and reduction of uncertainty: Environmental liabilities in the chemical industry. Rev. Quant. Financ. Account. 2003, 21, 349-378. [CrossRef]

60. Murray, A.; Sinclair, D.; Power, D.; Gray, R. Do financial markets care about social and environmental disclosure? Further evidence and exploration from the UK. Account. Audit. Account. J. 2006, 19, 228-255. [CrossRef]

61. Plumlee, M.; Brown, D.; Hayes, R.M.; Marshall, R.S. Voluntary environmental disclosure quality and firm value: Further evidence. J. Account. Public Policy 2015, 34, 336-361. [CrossRef]

62. Haniffa, R.M.; Cooke, T.E. The impact of culture and governance on corporate social reporting. J. Account. Public Policy 2005, 24, 391-430. [CrossRef]

63. Magness, V. Strategic Posture, financial performance and environmental disclosure: An empirical test of legitimacy theory. Account. Audit. Account. J. 2006, 19, 540-563. [CrossRef]

64. Stanny, E.; Ely, K. Corporate environmental disclosures about the effects of climate change. Corp. Soc. Responsib. Environ. Manag. 2008, 15, 338-348. [CrossRef]

65. Stanny, E. Voluntary disclosures of emissions by US firms. Bus. Strategy Environ. 2013, 22, 145-158. [CrossRef]

66. Clarkson, P.M.; Li, Y.; Richardson, G.D.; Vasvari, F.P. Revisiting the relation between environmental performance and environmental disclosure: An empirical analysis. Account. Organ. Soc. 2008, 33, 303-327. [CrossRef]

67. Lang, M.; Lundholm, R. Cross-Sectional Determinants of Analyst ratings of corporate disclosures. J. Account. Res. 1993, 31, 246-271. [CrossRef]

68. Hackston, D.; Milne, M. Some determinants of social and environmental disclosures in New Zealand companies. Account. Audit. Account. J. 1996, 9, 77-108. [CrossRef]

69. King, R.; Pownall, G.; Waymire, G. Expectations adjustment via timely management forecasts: Review, synthesis, and suggestions for future research. J. Account. Lit. 1990, 9, 113-144.

70. Ben-Amar, W.; Mcllkenny, P. Board effectiveness and the voluntary disclosure of climate change information. Bus. Strategy Environ. 2015, 24, 704-719. [CrossRef]

71. Liao, L.; Luo, L.; Tang, Q. Gender diversity, board independence, environmental committee and greenhouse gas disclosure. Br. Account. Rev. 2015, 47, 409-424. [CrossRef]

72. Andrikopoulos, A.; Kriklani, N. Environmental disclosure and financial characteristics of the firm: The case of Denmark. Corp. Soc. Responsib. Environ. Manag. 2013, 20, 55-64. [CrossRef] 
73. Freedman, M.; Jaggi, B. An Analysis of the association between pollution disclosure and economic performance. Account. Audit. Account. J. 1988, 1, 43-58. [CrossRef]

74. Roberts, R.W. Determinants of corporate social responsibility disclosure: An application of stakeholder theory. Account. Organ. Soc. 1992, 17, 595-612. [CrossRef]

75. Matisoff, D.C.; Noonan, D.S.; O'Brien, J.J. Convergence in environmental reporting: Assessing the Carbon Disclosure Project. Bus. Strategy Environ. 2013, 22, 285-305. [CrossRef]

76. Bewley, K.; Li, Y. Disclosure of environmental information by Canadian manufacturing companies: A voluntary disclosure perspective. In Advances in Environmental Accounting \& Management; Emerald Group Publishing Limited: Bingley, UK, 2000; pp. 201-226.

77. Jensen, M.C.; Meckling, W.H. Theory of the firm: Managerial behavior, agency costs and ownership structure. J. Financ. Econ. 1976, 3, 305-360. [CrossRef]

78. Bushee, B.J.; Noe, C.F. Corporate disclosure practices, institutional investors, and stock return volatility. J. Account. Res. 2000, 38, 171-202. [CrossRef]

79. Hassan, O.A.; Romilly, P. Relations between corporate economic performance, environmental disclosure and greenhouse gas emissions: New insights. Bus. Strategy Environ. 2018, 27, 893-909. [CrossRef]

80. Li, D.; Huang, M.; Ren, S.; Chen, X.; Ning, L. Environmental legitimacy, green innovation, and corporate carbon disclosure: Evidence from CDP China 100. J. Bus. Ethics 2018, 150, 1089-1104. [CrossRef]

81. Luo, L.L.; Tang, Q. Does national culture influence corporate carbon disclosure propensity? J. Int. Account. Res. 2015, 15, 17-47. [CrossRef]

82. Jiang, H.; Habib, A. The impact of different types of ownership concentration on annual report voluntary disclosures in New Zealand. J. Account. Res. 2009, 22, 275-304. [CrossRef]

83. Kim, E.H.; Lyon, T. When does institutional investor activism increase shareholder value? The Carbon Disclosure Project. BE J. Econ. Anal. Policy 2011, 11, 1-29. [CrossRef]

84. Harmes, A. The limits of carbon disclosure: Theorizing the business case for investor environmentalism. Glob. Environ. Polit. 2011, 11, 98-119. [CrossRef]

85. Jaggi, B.; Allini, A.; Macchioni, R.; Zagaria, C. The factors motivating voluntary disclosure of carbon information: Evidence based on Italian listed companies. Organ. Environ. 2018, 31, 178-202. [CrossRef]

86. Bose, S.; Khan, H.Z.; Rashid, A.; Islam, S. What drives green banking disclosure? An institutional and corporate governance perspective. Asia Pac. J. Manag. 2018, 35, 501-527. [CrossRef]

87. Mackenzie, C.; Rees, B.; Rodionova, T. The Impact of a Socially Responsible Investment Index on Climate Change Management and Carbon Emissions. 2016. Available online: https:/ / papers.ssrn.com/sol3/papers. cfm?abstract_id=2794613 (accessed on 17 July 2018).

88. Hermawan, A.; Aisyah, I.S.; Gunardi, A.; Putri, W.Y. Going green: Determinants of carbon emission disclosure in manufacturing companies in Indonesia. Int. J. Energy Econ. Policy 2018, 8, 55-61.

89. Campbell, D. Intra-and intersectoral effects in environmental disclosures: Evidence for legitimacy theory? Bus. Strategy. Environ. 2003, 12, 357-371. [CrossRef]

90. Hoffmann, V.H.; Busch, T. Corporate carbon performance indicators: Carbon intensity, dependency, exposure, and risk. J. Ind. Ecol. 2008, 12, 505-520. [CrossRef]

91. Luo, L. The influence of institutional contexts on the relationship between voluntary carbon disclosure and carbon emission performance. Account. Financ. 2017. [CrossRef]

92. Orsato, R.J.; de Campos, J.G.F.; Barakat, S.R.; Nicolletti, M.; Monzoni, M. Why join a carbon club? A study of the banks participating in the Brazilian “Business For Climate Platform". J. Clean. Prod. 2015, 96, 387-396. [CrossRef]

93. Jensen, M.C. Value maximization and the corporate objective function. In Breaking the Code of Change; Beer, M., Nohria, N., Eds.; Harvard Business School Press: Boston, MA, USA, 2000; pp. 37-58.

94. Saka, C.; Oshika, T. Disclosure effects, carbon emissions and corporate value. Sustain. Account. Manag. Policy J. 2014, 5, 22-45. [CrossRef]

95. Liu, Y.; Zhou, X.; Yang, J.; Hoepner, A.G. Corporate Carbon Emissions and Financial Performance: Does Carbon Disclosure Mediate the Relationship in the UK? 2017. Available online: https:/ / papers.ssrn.com/ sol3 / papers.cfm?abstract_id=2941123 (accessed on 17 July 2018).

96. Jacobs, B.W.; Singhal, V.R.; Subramanian, R. An empirical investigation of environmental performance and the market value of the firm. J. Oper. Manag. 2010, 28, 430-441. [CrossRef] 
97. Said, R.; Hj Zainuddin, Y.; Haron, H. The relationship between corporate social responsibility disclosure and corporate governance characteristics in Malaysian public listed companies. Soc. Responsib. J. 2009, 5, 212-226. [CrossRef]

98. Bui, B.; Houqe, N.; Zaman, M. Carbon Embedded Governance: Effects on Disclosure and Performance 2017. Available online: https: / / papers.ssrn.com/sol3 / papers.cfm?abstract_id=3092901 (accessed on 17 July 2018).

99. Kılıç, M.; Kuzey, C. Determinants of forward-looking disclosures in integrated reporting. Manag. Audit. J. 2018, 33, 115-144. [CrossRef]

100. de Villiers, C.; Naiker, V.; Van Staden, C.J. The effect of board characteristics on firm environmental performance. J. Manag. 2011, 37, 1636-1663. [CrossRef]

101. CDP. Climate Change Report Turkey Edition 2016. Available online: https:/ /cdpturkey.sabanciuniv.edu/ en/content/cdp-turkey-climate-change-report-2016 (accessed on 5 July 2017).

102. Hall, M.; Weiss, L. Firm size and profitability. Rev. Econ. Stat. 1967, 49, 319-331. [CrossRef]

103. Hymer, S.; Pashigian, P. Firm size and rate of growth. J. Polit. Econ. 1962, 70, 556-569. [CrossRef]

104. Demsetz, R.S.; Strahan, P.E. Diversification, Size, and risk at bank holding companies. J. Money Credit Bank. 1997, 29, 300-313. [CrossRef]

105. Amato, L.H.; Amato, C.H. The Effects of firm size and industry on corporate giving. J. Bus. Ethics 2007, 72, 229-241. [CrossRef]

106. Nazir, M.S.; Afza, T. Impact of aggressive working capital management policy on firms' profitability. IUP J. Appl. Financ. 2009, 15, 19.

107. Artiach, T.; Lee, D.; Nelson, D.; Walker, J. The determinants of corporate sustainability performance. Account. Financ. 2010, 50, 31-51. [CrossRef]

108. Roychowdhury, S.; Watts, R.L. Asymmetric timeliness of earnings, market-to-book and conservatism in financial reporting. J. Account. Econ. 2007, 44, 2-31. [CrossRef]

109. Chen, L.; Zhao, X. On the relation between the market-to-book ratio, growth opportunity, and leverage ratio. Financ. Res. Lett. 2006, 3, 253-266. [CrossRef]

110. Sáenz, J. Human capital indicators, business performance and market-to-book ratio. J. Intell. Cap. 2005, 6, 374-384. [CrossRef]

111. Haniffa, R.M.; Cooke, T.E. Culture, corporate governance and disclosure in Malaysian corporations. Abacus 2002, 38, 317-349. [CrossRef]

112. Midi, H.; Sarkar, S.K.; Rana, S. Collinearity diagnostics of binary logistic regression model. J. Interdiscip. Math. 2010, 13, 253-267. [CrossRef]

113. Yang, R.; Long, R. Analysis of the influencing factors of the public willingness to participate in public bicycle projects and intervention strategies-A case study of Jiangsu Province, China. Sustainability 2016, 8, 349. [CrossRef]

114. OECD. Corporate Governance Factbook. 2017. Available online: http://www.oecd.org/daf/ca/corporategovernance-factbook.htm (accessed on 20 July 2018).

115. Jianu, I.; Jianu, I. The share price and investment: Current footprints for future oil and gas industry performance. Energies 2018, 11, 448. [CrossRef]

116. Camburn, E.M. College completion among students from high schools located in large metropolitan areas. Am. J. Educ. Res. 1990, 98, 551-569. [CrossRef]

117. Spiess, M. Evaluation of a Pseudo-R2 measure for panel probit models. Br. J. Math. Stat. Psychol. 2001, 54, 325-333. [CrossRef]

118. Kılıç, M.; Kuzey, C. The effect of corporate governance on carbon emission disclosures: Evidence from Turkey. Int. J. Clim. Chang. Strateg. Manag. 2018. [CrossRef]

119. Prado-Lorenzo, J.M.; Rodríguez-Domínguez, L.; Gallego-Alvarez, I.; García-Sánchez, I.M. Factors influencing the disclosure of greenhouse gas emissions in companies world-wide. Manag. Decis. 2009, 47, 1133-1157. [CrossRef]

120. Jensen, M.C. The Modern industrial revolution, exit, and the failure of internal control systems. J. Financ. 1993, 48, 831-880. [CrossRef] 
121. Hidalgo, R.L.; Garcia-Meca, E.; Martinez, I. Corporate Governance and intellectual capital disclosure. J. Bus. Ethics 2011, 100, 483-495. [CrossRef]

122. Boone, A.L.; Field, L.C.; Karpoff, J.M.; Raheja, C.G. The determinants of corporate board size and composition: An empirical analysis. J. Financ. Econ. 2007, 85, 66-101. [CrossRef] 